\title{
The Effect of Sport and Circulo Massage on the Improvement of Work Productivity of the Physically Disabled
}

\author{
Sumarjo ${ }^{1-4 *}$ \\ ${ }^{I}$ Doctoral Program in Development Extension \\ Graduate School, Sebelas Maret University \\ ${ }^{2}$ Doctoral Program in Sport Science \\ Graduate School, Sebelas Maret University \\ ${ }^{3}$ Doctoral Program in Public Health \\ Graduate School, Sebelas Maret University \\ ${ }^{4}$ Installation of Medical Rehabilitation \\ RSUD Dr.Muwardi \\ Surakarta, Indonesia \\ Corresponding author: \\ *sumarjopp@student.uns.ac.id
}

\author{
Agus Kristiyanto ${ }^{2}$ \\ ${ }^{2}$ Doctoral Program in Sport Science \\ Graduate School, Sebelas Maret University \\ Surakarta, Indonesia \\ Endang Sutisna Sulaeman \\ ${ }^{3}$ Doctoral Program in Public Health \\ Graduate School, Sebelas Maret University \\ Surakarta, Indonesia \\ Noer Rahma ${ }^{4}$ \\ ${ }^{4}$ Installation of Medical Rehabilitation \\ RSUD Dr.Muwardi \\ Surakarta, Indonesia
}

\begin{abstract}
- the research intends to determine the difference of sport massage and circulo massage based on the direction of distal and proximal massage of people with physical disability in influencing their performance productivity which consists of motivation, knowledge, skill and attitude. The discussion will be done by comparing the two combinations. The subjects used in this research were people with monoplegia disabilities who participated in the State Integrated Disability Rehabilitation Centre (BRTPD) program in Yogyakarta. The samples were taken from the existing population by the Purposive Random Sampling method. The data collection was obtained by questionnaire. The form of questionnaire work productivity consists of four criteria: 1) motivation, 2) knowledge, 3) skill, 4) attitude. The data analysis technique used the multivariate analysis with Repeated Measured test. The research results can provide recommendations on the most effective massage methods and training programs that can be applied to people with physical disabilities and also, the results obtain criteria for identification of measurement procedures and improvement of work productivity in physical disability which consists of motivation, knowledge, skill and attitude. Both combinations of the training are expected to find out the effect of improving the productivity of work productivity on people with physical disabilities.
\end{abstract}

Keywords—sports, circulo, massage, work productivity

\section{INTRODUCTION}

Health development is an integral part of the development of human resources (HR), to achieve the development of an advanced, independent, and prosperous nation physically and spiritually. Human resource development starts from the womb till birth, far before paying attention to the toddler, school age, youth, and productive age to old age. Health promotion is the process of making people able to improve the control of health and to improve their health. One of the goals of health promotion is to change behaviour or provide information to the target leading to better behaviours or give positive behaviours, and eliminate negative behaviours.

Changes in social behaviours are changes that occur due to discrepancies among different social elements in people's lives, resulting in a new pattern of life. Social changes includes changes in social values, social norms, social organization structures, social coatings, social groups, social interactions, patterns of behaviours, power and authority, and various other aspects of community life [1]. [2] Social change is a change in social institutions in a society.

Social change can be concluded as a change that shows up in social structure and function. Social change is closely related to cultural change, and often, social change is related to cultural habit [3]. Social change is a process, which covers the overall form of aspects of community life. The social changes that occur in community development are also needed to build the community and to build a society because every unit of society has community power [4].

The health life status of community is determined by the health conditions of the citizens, including the condition of parents, adolescents, and children. Efforts to improve public health have become a major program in order to improve the quality of family life through community education. Regarding this, the role of family and school becomes important, as the realization of ideas formulated in the national development goals. The realization of quality generation is for the development of the nation and state, including for people with disabilities. People with different abilities are people who differ both physically and mentally [5]. All limitations owned by the community cannot be used as an excuse for them or anyone to carry out social restrictions either directly or indirectly. This social limitation occurs when those who have physical limitations have been grouped in disability foundations or in special schools, and social restrictions. This is increasingly evident when the 
environment around us and the city public spaces causes every step of their crutches to stumble, every one of their wheelchairs stopped, every swing of their blind white stick blocked, and every sign language ignored by the community.

The productivity of disability workers by providing various skills has been sought by the Government of Indonesia. Through the program at the Rehabilitation Centre for Disabled People, people with disabilities are trained to learn and master various skills. Productivity itself is an ability to produce something. A high level of productivity can be achieved through several supporting factors. The supporting factors include: Education, skills, attitudes, and work ethics, income level, social security, social level, and work climate, motivation, nutrition and health, individual relations, technology, and production.

Giving skills to people with disabilities is the fulfilment of needs which is in accordance with the needs based on the potential they have and can be further enhanced towards independence. Through skills training programs aimed at people with disabilities, especially the provision of training in sports massage and circulo massage types, they are expected to have more decent quality of life and can break the perception that people with disabilities are burden in their lives by begging somewhere.

\section{METHOD}

\section{A. Design and Sample}

This research was conducted using the quantitative research by the quasi-experimental research method. The treatment group was measured by giving a type of massage that uses a Sport Massage and Circulo Massage technique with distal and proximal massage directions to increase work productivity in disabled people. The research used $2 \times 2$ factorial designs. In this research, the population were people with disabilities specifically monoplegia disabled people who have the following characteristics:

- Male sex

- $\quad$ Age 20-30 years old

- Physical disability / disability occurred in only one limb that is paralyzed at the bottom

- Persons with disabilities who participate in the program at the Integrated Rehabilitation Centre for Disabled People (BRTPD) in Pundong District, Bantul Regency, Special Region of Yogyakarta who were going to schools and those who were not.

The samples in this research were taken from the existing population by using the Purposive Random Sampling. The size of the sample was determined by the formula of Isaac and Michael [6].

\section{B. Data Collection and Research Instrument}

Data collection was obtained using the questionnaire. The instrument used to measure work productivity in this research used the questionnaire consisting of four influencing factors, namely: 1) motivation, 2) knowledge, 3) skills, and 4) attitude.

\section{Data Analysis Technique}

Data analysis technique used in this research is as follows:

\section{Prerequisite Test}

a) The normality test was conducted to test if the analysed variables had data normal distribution. The Data normality test was carried out by using Kolmogorov Smirnov Z.

b) The homogeneity test was used to test the similarity of the variance in the results of the data on each treatment group. The Homogeneity test was performed on the research data of the pretest and posttest observations. The statistical test used to test the homogeneity of variance was the F-test, which compared the largest variance with the smallest variance.

c) The $T$ test was done to find out whether there were differences in variables in each group. The results of the analysis stated that there was a difference if the significance value was less than $0.05(\mathrm{P}<0.05)$.

\section{Hypothesis Test}

The Multivariate analysis (MANOVA) by Repeated Measured test was conducted to test the hypothesis, which is to find out the difference between the dependent variable and the independent variable with significance level more than of 0.05 .

\section{FINDINGS AND DISCUSSION}

\section{A. Research Result}

Based on the results of the MANOVA analysis on the training method, the $p$ value obtained is $<0.05$ (sig. smaller than 0.05$)$, so, the sport massage training method from the distal direction (cell 1), sport massage training method from the proximal direction (cell 2), circulo distal massage (cell 3 ), and circulo massage from the proximal direction (cell 4), use four statistical models, which include: 1) Pillai's Trace, 2) Wilks' Lambda, 3) Hotelling's Trace and 4) Roy's Largest Root, obtained a significance value of 0.000 , smaller than $0.05(p<0.05)$, so, it can be concluded that the described sport massage training method from the distal direction (cell 1 ), training of sport massage from the proximal direction (cell 2), circulo massage from the distal direction (cell 3), and circulo massage from the proximal direction (cell 4), have significant effects on increasing work productivity which consists of motivation, knowledge, skills, and attitudes.

Based on the results of the MANOVA analysis on the circuit training method and circuit trapping combined with the direction of massage from the distal and proximal points, thus, the following conclusions can be drawn:

1. The most effective motivational improvement is in cell 1.2 which is obtained by using the sport massage training method from the proximal direction.

2. The most effective increase in knowledge in cell 1.1 is obtained by using the sport massage training method from the distal direction. 
3. The most effective skill and attitude improvement in cell 2.1 is obtained by using the circulo massage method from the distal direction.

The summary of the lower bound of 4 (four) cells based on confidence interval can be seen in the following table:

TABLE I. SUMMARY OF LOWER BOUND

\begin{tabular}{|c|c|c|c|}
\hline \multirow{3}{*}{$\begin{array}{l}\text { Massage } \\
\text { Method }\end{array}$} & \multirow{3}{*}{$\begin{array}{l}\text { Dependent } \\
\text { Variable } \\
\text { (Work } \\
\text { Productivity) }\end{array}$} & \multicolumn{2}{|c|}{ Direction of Massage } \\
\hline & & Distal & Proximal \\
\hline & & $\begin{array}{l}\text { Lower } \\
\text { bound }\end{array}$ & $\begin{array}{l}\text { Lower } \\
\text { bound }\end{array}$ \\
\hline \multirow{4}{*}{ Sport Massage } & Motivation & 48 & 52 \\
\hline & Knowledge & 53 & 50 \\
\hline & Skill & 48 & 47 \\
\hline & Attitude & 51 & 49 \\
\hline \multirow{4}{*}{$\begin{array}{l}\text { Circulo } \\
\text { Massage }\end{array}$} & Motivation & 51 & 50 \\
\hline & Knowledge & 52 & 51 \\
\hline & Skill & 54 & 50 \\
\hline & Attitude & 55 & 52 \\
\hline
\end{tabular}

\section{B. Discussion}

The results of this study indicate that a lot of effective massage training methods which are known to increase motivation, knowledge, skill, and attitude. The most effective massage training which increases motivation is the sport massage method from the proximal direction. The most effective massage training to increase knowledge is the sport massage method from the distal direction. While to improve skill and attitude, the most effective training method is the circulo massage method from the distal direction. So, it can be concluded that the most effective massage training method to increase the work productivity component is the circulo massage method from the distal direction because in all dependent variables, the changes are significant and there are two variables that experience the highest changes, which are skill and attitude.

The Circulo massage is a mainly targets the blood and lymph circulation with the mainstay technique of friction. The Circulo massage aims to restore fatigue and obtain a higher fitness level. The massage produces endorphins derived from frictional movements. The endorphins function as a sedative. The Circulo massage also produces thyroxin hormone which facilitates the body's metabolism. Thyroxin hormone is obtained from effleurage and tapotement techniques. Adrenaline hormones are also produced by the circulo massage by using tapotement technique which stimulates the sympathetic nerves [7]. The research [8] shows that hand massage can cause relaxation and calmness.

1. The Difference between the Sport Massage and Circulo Massage Training Method

This research shows that differences in sports massage and circulo massage training methods can have an effect on work productivity which consists of motivation, knowledge, skill and attitude. The circulo massage training method when compared to the sports massage training method can make greater contribution to the improvement of skills and attitudes. However, the Sport massage training method is more productive in increasing motivation and knowledge.

The Sport massage has various manipulations, including: efflurage (rubbing), petrissage (shuffling), shaking, tapotement (hitting), friction, walken, vibration (vibrating), stroking (sorting), skin- rolling (folding the skin), chiropractic (tapping). The Sport massage can produce several hormones such as endorphins, adrenaline, and thyroxine. Endorphins are obtained from effleurage and frictional techniques. Endorphins are tranquilizing hormones. Thyroxine hormones are derived from petrisase movement techniques, tapotement, effleurage, shaking, and walken. The hormone aims to transport the body's waste metabolism. The Adrenaline hormone controls the nervous system and is obtained from the tapotement movement. Sport massage stimulates the peripheral nerves from tapotement, stroking, effleurage [9].

The mainstay technique in circulo massage is friction with circular motion. The tapotement intends to maximize the results of friction, and the effleurage to calm the body down. At the beginning of the massage, intentionally friction is applied immediately to cause shock and stimulate the release of endorphins which function as tranquilizers. The entire body from the feet sole to every part will be manipulated by the circulo massage considering the arrangement of muscles and the way the organs work. The manipulation or grip is a method of using the hands to perform circulo massage in certain areas, as well as giving certain influences. The various circulo massage manipulations used include: friction, tapotement, walken (pulling and pushing), effleurage (rubbing), and skin rolling (folding the skin) [10].

2. The Difference between Distal and Proximal Massage Direction

The research shows that there are significant differences in the direction of massage from distal and proximal to boost the productivity. The difference in massage direction with the largest contribution to the increase in motivation, knowledge, skills, and attitude is found in the distal direction of massage when compared to the proximal massage direction.

In various studies, it is stated that samples after participating in the training program have better attitude [11]. Physical rehabilitation of athletes with disabilities by massaging can encourage the development of compensation mechanisms, restore and enhance the ability of manipulative actions, improve pathological conditions associated with the underlying disease and related ones [12]. The medium of physical rehabilitation improves the application of the thermoregulation process, stimulates the work of peripheral vessels, increases metabolism, and improves regional blood flow.

3. Interaction of Massage Training Method with Massage Direction

This research shows that there are significant interactions between the sport and circulo massage training methods with distal and proximal massage directions on work productivity. This significant interaction shows that in all four treatment groups combining the massage methods, it can have an effect on increasing work productivity. 
[13] Massage therapy benefits Attention Deficit Disease Activity Disoder (ADHD) students by improving their shortterm mood and long-term class behavior. [14] The Massage cupping is not more effective than the progressive muscle relaxation in reducing chronic non-specific neck pain. Both massage cupping therapies and Progressive Muscle Relaxation (PMR) can be easily used at home to reduce pain at a low clinical level. However, the cupping massage may be better than PMR in improving well-being and reducing the sensitivity of pressure pain but more research with larger samples and longer follow-up periods is needed to confirm these results.

Based on the discussion of the research results on the effect of sport massage and circulo massage training with distal and proximal massage directions on work productivity consisting of motivation, knowledge, skill and attitude, it can be seen as a whole in the following table:

TABLE II. SUMMARY OF RESEARCH RESUlt OF THE TRAINING METHOD

\begin{tabular}{|c|l|l|}
\hline No & \multicolumn{1}{|c|}{ Training Method } & \multicolumn{1}{c|}{ Result } \\
\hline 1. & $\begin{array}{l}\text { Sport massage with distal } \\
\text { massage direction }\end{array}$ & $\begin{array}{l}\text { Biggest Increase on Knowledge } \\
\text { Variable }\end{array}$ \\
\hline 2. & $\begin{array}{l}\text { Sport massage with } \\
\text { proximal massage direction }\end{array}$ & Biggest Increase on Motivation \\
\hline 3. & $\begin{array}{l}\text { Circulo massage with distal } \\
\text { massage direction }\end{array}$ & $\begin{array}{l}\text { Biggest Increase on Skill and } \\
\text { Attitude }\end{array}$ \\
\hline 4. & $\begin{array}{l}\text { Circulo massage with } \\
\text { proximal massage direction }\end{array}$ & $\begin{array}{l}\text { Training method with no } \\
\text { significant result on one of the } \\
\text { variables, but all variables } \\
\text { increase. }\end{array}$ \\
\hline
\end{tabular}

\section{CONCLUSION}

Based on the research results on the effect of sports massage and circulo massage training with distal and proximal massage directions on work productivity which consists of motivation, knowledge, skill and attitude, the following conclusions can be drawn:

1. Sports massage and circulo massage training methods have effects on work productivity. Increased knowledge and motivation variables are more effective using the sport massage training method. While the increase in skill and attitude variable is more effective using the circulo massage training method.

2. There is a significant difference in the direction of massage from distal and proximal to increase work productivity. The massage direction that produces the largest contribution to the increase productivity is found in the distal direction of massage when compared to the proximal massage direction.

3. There is a significant interaction of sports massage and circulo massage training methods with distal and proximal massage directions towards work productivity.

\section{REFERENCES}

[1] N. Djazifah, "Proses perubahan sosial di masyarakat. modul pembelajaran sosiologi”. Lembaga Penelitian dan Pengabdian Kepada Masyarakat Universitas Negeri Yogyakarta, 2012.

[2] Anwar, Yesmil, Adang, "Sosiologi untuk Universitas". Bandung, Refika Aditama, 2013.
[3] Baharuddin, "Bentuk-Bentuk Perubahan Sosial dan Kebudayaan", 2013. http//jurnaliainpontianak.or.idindex

[4] M. Mulyadi, "Perubahan Sosial Masyarakat Argaris Ke Masyaraka Industri dalam Pembangunan Masyarakat di Kecamatan Tamalate Kota Makassar”. Jurnal Bina Praja, 2015, vol. 7, no. 4.

[5] K. Deswanto, "Studi Persepsi Masyarakat terhadap Tingkat Kepentingan Penyediaan Ruang Terbuka Publik (RTP) yang Aksessibel Bagi Masyarakat Difabel (Studi Kasus : Alun-Alun Utara Solo)", Universitas Diponegoro, Semarang, 2004.

[6] Sugiyono, "Metode Penelitian Kombinasi (Mixed Methods)". Bandung, Alfabeta, 2013.

[7] W. Kushartanti, "Pelatihan Circulo Massage". Yogyakarta, Klinik Terapi Fisik Fakultas Ilmu Keolahragaan Universitas Negeri Yogyakarta, Makalah, 2003.

[8] C. Peter, "The Theraupetic effect of hands massage". Learning Disability Practice, 2009, vol. 12, no. 5, p. 29.

[9] B. Wijanarko, S. Riyadi, "Sport massage Teori dan Praktik". Surakarta, Yuma Pustaka, 2010.

[10] Tim Klinik Terapi Fisik FIK UNY, "Pelatihan Circulo Massage". Yogyakarta, Klinik Terapi Fisik Fakultas Ilmu Keolahragaan Universitas Negeri Yogyakarta, Makalah, 2008.

[11] J. E. Maclaren, L. C. Lindsey, T. L. Kevin, N. S. Elisabeth, "Training Nursing Students In Evidence-Based Techniques for CognitiveBehavioral Pediatric Pain Management", Journal of Nursing Education, 2008, vol. 47, no. 8.

[12] R. Rudenko, A. Mahliovanyy, O. Shyyan, T. Prystupa, "Physical Rehabilitation and Thermoregulatory Proceses in Athletes with Disabilities". Journal of Physical Education and Sport, 2017, pp. 730735.

[13] S. Khilnani, T. Field, H. R. Maria, S. Schanberg, "Massage Therapy Improves Mood and Behavior of Students with AttentionDeficitihyperactivity Disorder”. Adolescence, 2003, vol. 38, no. 152.

[14] L. Romy, M. Svitlana, C. Holger, H. Heidemarie, S. Rainer et al., "Effectiveness of Home-Based Cupping Massage Compared to Progressive Muscle Relaxation in Patients with Chronic Neck Pain-A Randomized Controlled Trial”, 2013, vol. 8, no. 6. 